\title{
ATTITUDES TOWARD A CODE OF ETHICS: A COMPARISON BETWEEN ACADEMIC AND NON-ACADEMIC STAFF
}

\author{
Martinus Parnawa Putranta \\ Faculty of Business and Economics, Universitas Atma Jaya Yogyakarta, Indonesia \\ Email: parnawa.putranta@uajy.ac.id
}

Received: June 2020; Accepted: July 2020; Available online: July 2020

\begin{abstract}
The unethical conduct of practitioners in profit and nonprofit organizations is frequently revealed in the mass media. Many of those who engage in such conduct had ever spent their time studying at universities. This issue poses a challenge for universities in fostering a learning environment enabling students to increase moral awareness in their professional lives. In this regard, university employees play important roles in providing a moral model. Thus, research on their ethical attitudes is essential. This study aimed to determine the ethical attitudes of academic and non-academic staff at a denominational university in Indonesia by identifying their attitudes towards their institutional code of ethics. Of the 200 distributed questionnaires, only 103 (50\%) returned. Generally, the results suggested the staff had relatively positive attitudes towards the code. The difference in the attitude between the two groups was not found. These attitudes indeed do not assure the actual ethical behaviors of the staff. However, understanding the attitudes can help the institution anticipate any possible ethical violations from the staff. This article also discusses a range of managerial actions to create the institution's ethical environment and the theoretical implications of this research.
\end{abstract}

Keywords: codes of ethics; university; denominational; staff; Indonesia.

\begin{abstract}
Abstrak
Perilaku tidak etis para praktisi di organisasi laba dan nirlaba sering diungkap di media massa. Banyak dari mereka yang terlibat dalam perilaku tersebut pernah meluangkan waktu untuk belajar di universitas. Isu ini menimbulkan tantangan bagi universitas dalam menumbuhkan lingkungan belajar yang memungkinkan mahasiswa meningkatkan kesadaran moral dalam kehidupan profesional mereka. Dalam hal ini, karyawan universitas memainkan peran penting. Mereka dituntut untuk memberikan teladan moral. Oleh karena itu, penelitian tentang sikap etis mereka diperlukan. Penelitian ini bertujuan untuk mengetahui sikap etika dari staf akademik dan non-akademik di sebuah universitas berafiliasi kegamaan di Indonesia dengan cara mengidentifikasi sikap karyawan terhadap kode etik di institusi mereka. Dari 200 kuesioner yang disebar, hanya 103 (50\%) yang kembali. Secara umum, hasil penelitian mengindikasikan para staf mempunyai sikap yang relatif positif terhadap kode etik mereka. Tidak ditemukan perbedaan sikap di antara karyawan akademik dan nonakademik. Sikap etis memang tidak menjamin perilaku etis yang sesungguhnya dari para staf. Namun, memahami sikap etis tersebut dapat membantu institusi mengantipasi kemungkinan terjadinya pelanggaran etika dari para staf tersebut. Dalam artikel ini juga dibahas serangkaian tindakan manajerial yang diperlukan agar lingkungan kerja yang etis dapat tercipta serta implikasi teoritis dari penelitian ini.
\end{abstract}

Kata kunci: kode etik; universitas; afiliasi keagamaan; staf; Indonesia

How to Cite: Putranta, M. P. (2020). Attitudes Toward a Code of Ethics: a Comparison between Academic and NonAcademic Staff. Media Ekonomi dan Manajemen, 35(2), 243-257. doi: http://dx.doi.org/10.24856/mem.v35i2.1575. 


\section{INTRODUCTION}

Unethical conduct of practitioners are frequently reported in television, newspaper and other media. It is interesting that many of those practitioners involved in the misconduct have ever had spent their time studying at higher education institutions. This issue poses a significant challenge for higher education institutions to create a better learning environment which enables their students to equip themselves with necessary skills to become ethical leaders as well as citizens (Weegar, 2007). In this context, employees within the institutions are in the front line in fostering such environment. They are required to provide role models through practicing ethical attitudes and behaviors within and beyond the institutions (Couch \& Dodd, 2005). Therefore, understanding the ethical attitudes of these employees is imperative considering such attitudes will affect their ethical reasoning (Valentine \& Barnett, 2002).

The purpose of this research was to ascertain the ethical attitudes of employees who worked in a denominational higher education institution in Indonesia. The ethical attitudes of the employees were assessed by investigating their attitudes towards their existing code of ethics. The code of ethics was favored because it has been regarded as a popular tool (Ibrahim, Angelidis, \& Igor, 2009) and one indication of organizations' serious attempts to demonstrate their concerns with ethics (Ashkanasy, Falkus, \& Callan, 2000). Embracing codes of ethics is also generally perceived as the first step and good start to reduce unethical conducts in the workplace (Kaptein, 2011) and to positively influence ethical environment (Ashkanasy et al, 2000; Pauli, Arthur, \& Price, 2014; Valentine \& Barnett, 2002) as the codes provide explicit guidelines for acceptable and unacceptable conducts for the members of the organizations (BarnardBrak, Schmidt, \& Wei 2013; Magalhães,
Pereira, Nascimento, Bruno, de Lima. \& Mardson, 2016).

Previous research have confirmed a positive link between the existence of codes of ethics and employees' ethical perceptions and attitudes. Valentine \& Barnett (2002), for example, showed sales professionals who worked for organizations with codes of ethics perceived their workplace as having more positive ethical environment than did other sales professionals. A study of Adams, Tashchian, and Shore (2001) indicated employees from companies with codes of ethics felt more encouraged and supported for ethical behavior than those employees from companies without codes. Another research reported employees who worked in public relations companies with ethics codes tended to display higher ethical standards than their counterparts who worked for similar companies without codes (Ki, Lee, \& Choi, 2012).

Like other organizations, higher education institutions establish code of ethics to assure public that the institutions provide a set of rules and standards regarding acceptable behaviors which are useful for the institutions to shape the ways their members view their roles which in turn affect any aspects of organizational process within the institutions including the faculty-student relationship and administrative decision-making (Bray, Molina, \& Swecker, 2012). The mere existence of the code, however, will be meaningless if members of the institutions do not believe that the code is enforced properly (Poon \& Ainuddin, 2011). Therefore, an investigation on how employees within the institutions perceive their ethical code is managed is urgent. It is in this context that this research was conducted. The staffs' attitudes towards the code indeed do not promise their actual ethical behaviors. However, the attitudes could help the institution to predict their unethical behaviors and take necessary 
actions to create a positive ethical environment within the institution.

\section{Research Questions}

Codes of ethics cannot stand alone (Stevens, 1999). The effectiveness of the codes is dependent upon two main factors, namely, individual and situational factors (Ford \& Richardson, 1994). The first factor refers to variables relate results of birth (e.g. age and sex) and outcomes human development process (e.g. education and employment) while the second connotes variables such as top management influence and industry types ( $\mathrm{Ki}$ et al, 2012). This research focused primarily on the second individual factor. The rationale of the choice was based on assumptions underlying attribution theory that, people tend to frame individuals as causal agents when they find an unethical behavior of a person and then make personal attribution to explain the behavior rather than considering environmental factors that facilitate the behavior (Stevens, 1999). In particular, the purpose of this research endeavor was to discover whether employee occupation was a possible determinant of code effectiveness.

Employees working in higher education institutions can be divided into two major groups: academic and non-academic staff. The first group is usually responsible for research and teaching activities while the latter charged with supporting the jobs of the first group. On the basis of the aforementioned argument that these employees play important roles in fostering an ethical organizational environment this research aimed to examine the attitudes of academic and non-academic staff of a denominational university in Indonesia toward their existing code of ethics. The research was also to determine the extent to which these two group of employees possessed similar or different degree of attitudes towards the code.

\section{LITERATURE REVIEW}

Codes of Ethics

Ethics is the study of morality while morality itself is the standards or rules that people or society use to govern human behaviors and to consider whether the behaviors are good or bad (Arnold, Beauchamp, \& Bowie, 2013). These kinds of standards of behaviors can also be found in organizations and commonly known as codes of ethics (Fiedler \& van Haren, 2009).

Scholars have proposed various ideas of what the names of an ethical code are, ranging from code of ethics, code of conduct, business principles, corporate credo, code of practice and a value statement even though the most commonly used terms are "code of ethics" and "code of conduct" (Ho \& Oladinrin, 2016). In terms of definitions, the code has been explained in many ways. It is a distinct and formal document consisting moral standards or ethical principles developed by and for a company to govern the behaviors of the organizations members, external stakeholders and/or society in general (Kaptein \& Schwartz, 2008; Schwartz, 2001; Stevens, 1999) or interorganizational and intra-organizational practices and relations (Stohl, Stohl, \& Popova, 2009). The various definitions, however, share three common components. (Schwartz, 2004) The first concerns acceptable moral standards for behaviors within an organization. The second relates to whom do the moral standards apply. The third requires the explicit nature of the document.

A formal code of ethics has been considered as the most common tangible organizational tool (Valentine, Hanson, \& Fleischman, 2019) and the most frequently cited instrument (Kaptein, 2011) for an organization to legally manifest its expectation regarding the behavior of employees to be judged as ethical or not (Adelstein \& Clegg, 2016). This is to say 
that a code of ethics helps the employees and other stakeholders of an organization understand the difference between right and wrong behaviors (Chu, Gotti, Kang, \& Wolfe, 2018) and facilitates ethical reasoning and conduct (Ruiz-Palomino, Martinez-Canas, Ricardo, Rodrigo, \& Díaz-García, 2015).

Organizations have codes of ethics for a number of reasons. They may possess the codes just because it is the right thing to do (Kaptein \& Schwartz, 2008), it helps the organizations gain community recognition or to obey the law (Valentine \& Barnett, 2002) and decrease unacceptable behavior within the organizations (Sánchez, Rodríguez-Domínguez, and Frias-Aceituno, 2015). Wotruba, Chonko, and Loe (2001) note three major purposes of organizations to have ethical codes, namely, showing their ethical concerns, transferring the organizations' values to their members and influencing the ethical behaviors of the members.

There has been disagreement over whether embracing a code of ethics enables an organization to predict the ethical behaviors of its employees. However, the code at least is indicative of the organization's commitment to encourage such behaviors (Ashkanasy et al, 2000). There is also a reason to believe that the existence of a code of ethics will strengthen employees' perceptions that ethical conducts are reassured and unethical action are reprimanded (Valentine \& Barnett, 2002) even when employees cannot recall specific content of the code (Adams et al, 2001).

\section{Research on Codes of Ethics in Higher Education Institutions}

Some higher education institutions also have put their great efforts to create an ethical environment by introducing codes of ethics or commonly known as honor codes (McCabe, Trevino, \& Butterfield, 1996). An academic honor code is a public statement containing a set of general expectations about shared moral commitments used to endorse the academic integrity of an institution (Pauli et al, 2014)

Although a code of ethics and an honor code are somewhat different, the two terms are often used interchangeably for ethics initiative purposes (Pauli et al, 2014; Weber, 2006). The institution being studied in this research referred to "a code of ethics" to describe the rules and standards the institution used to govern the behaviors of its members. For this reason, the term "codes of ethics" are used throughout this article and the term connoted an official written document containing ethical standards used by the institution to guide the conducts of its members (i.e. academic and non-academic staff)

Overall, research on employees' perceptions and attitudes on codes of ethics in higher education institutions are relatively small compared to similar studies in business contexts. The most recent such investigations perhaps is that of Yahr, Bryan, and Schimmel (2009) that found the majority of staff from the surveyed institutions exhibiting positive attitudes towards the existence as well as the enforcement of the codes. Using a sample of 292 vice-presidents of finance of colleges and universities in America Rezaee, Elmore, and Szendi, (2001) showed respondents were generally supportive of the concept of codes of ethics in colleges and universities as the codes could provide a basis of ethical behaviors in the institutions. While the two studies are relevant to this research, none specifically addressed possible differences in attitudes between academic and nonacademic staff toward the codes.

Demographic variables at the individual level also have been examined whether they have potential for affecting employees' perceptions on codes of ethics, ranging from age, managerial level, job tenure, role responsibility (Ashkanasy, et al, 2000), work, tenure (Forte, 2004), 
education, management level (Mujtaba, Tajaddini, \& Chen, 2011), place of residence, monthly income, marital status (Lopez, Rechner, \& Olson-Buchanan, 2005) religious affiliation (Pauli et al, 2014) to schooling (Lam \& Shi, 2008). Although findings of the examinations shared a common conclusion that the use of codes of ethics is beneficial for the organizations they yielded conflicting results regarding the relationship between the demographic factors and codes of ethics. Furthermore, among the demographic factors, occupation is relatively unexplored. Therefore, this research aimed to fill his gap.

\section{Hypotheses}

There are two common terms relating the management of a code of ethics namely, implementation and embeddedness. Code implementation describes the degree to which an organization put its efforts to make the code conveyed and its compliance ensured whereas code embeddedness refers to the extent to which the code is integrated into the culture of the organization (McCabe et al, 1996; Oladinrin \& Ho, 2016). Therefore, the attitudes toward the code in this research referred the attitudes of the staff regarding the embeddedness and the implementation of the code in their institution.

Religious affiliation also has been believed to have potential for facilitating ethical behavior. A research conducted by Pauli et al (2014) showed students from a religiously affiliated university tended to be aware of a code of ethics and displayed a lower level of perceived acceptability of cheating compared to students from a public university. Furthermore, Pauli et al, argue that established religious institutions are generally formed on the basis universal moral principles. These principles are used as guidelines for interactions among their members with rules from outside or from the institutions and are explicitly supported and enforced. In such institutions, religious activities usually are endorsed hence the norms of religion are embedded in employees' minds. Positive norms inherent in religions will lead to the employees to engage in good things (Lukviarman, Ma'ruf, \& Hamidi, 2018) which in turn they favor the presence and enforcement of a code of ethics in their institution. Considering the institution being studied was an established religiously affiliated one it was very likely the positive norms of the religion were embedded in the minds of the institution members. In light of this view, the following hypotheses were developed:

H1a: Both academic and non-academic staff demonstrate positive attitudes towards the embeddedness of their institutional code of ethics.

H1b: Both academic and non-academic staff exhibit positive attitudes towards the implementation of their institutional code of ethics.

As previously described, higher education institutions play significant roles in developing future ethical leaders. In this context, academic and non-academic staff of the institutions are influential employees, therefore, when their behaviors come into questions the roles of higher educations are challenged. In view of this fact, ascertaining and comparing their ethical attitudes will be beneficial for the sampled institution in order to create the ethical environment of the institution.

Although it did not specifically address a code of ethics, a study of Rothman (2017) showed that administrators and full-time faculty of a 4-year private college in the USA perceived the organizational moral principles of the college influence their decision making and behaviors and strictly following the principles has led to their success within the college. There was no difference found in perception between the two groups. 
Implicit in the finding both the administrators and faculty favor the moral principles implemented and embedded in the college. Taking these findings into account and combined with the distinctive, religious nature of the surveyed institution a similar occurrence might take place in the institution. To this end, it was hypothesized that

$\mathrm{H} 2 \mathrm{a}$ : There is no significant difference between academic and non-academic staff with regard to their attitudes toward the embeddedness of their institutional code of ethics.

$\mathrm{H} 2 \mathrm{~b}$ : There is no significant difference between academic and non-academic staff with regard to their attitudes toward implementation of their institutional code of ethics.

\section{RESEARCH METHODS}

\section{Sample}

The research involved permanent staff of one denominational institution in Central Java, Indonesia. A purposive sampling was used to obtain the sample. A total of 200 questionnaires were distributed individually to the prospective respondents but only $103(50 \%)$ were useable. Out of the 103 respondents, $57(55.3 \%)$ male and $46(44.7 \%)$ female. In terms of occupations, the sample consisted of 51 $(49.5 \%)$ academic staff and $52(50.5 \%)$ non-academic staff. Majority $(81.6 \%)$ of the respondents were married and the remaining $18.4 \%$ were unmarried.

\section{Measures}

Staff's attitudes towards code of ethics were measured by using a twocomponent scale developed by McCabe et al (1996). The two-component scale consisted of 13 items with a 5-point Likert scale ranging from strongly disagree (1) to strongly agree (5). The first component called code embeddedness was measured using eight items while the second component named code implementation was assessed using five items. During the preliminary investigation, however, the scale was reduced to 10 . The investigation also revealed that the Cronbach's Alpha coefficients $(\alpha)$ were 0.831 for code embeddedness and 0.735 for code implementation scale indicating that each scale was acceptable.

\section{Procedures}

A back translation process was used to adapt the scale in the Indonesian context. Contact persons from the prospective institution were engaged to arrange the direct distribution and collection of the questionnaires after a permission to conduct the research was gained. A covering letter ensuring confidentiality and voluntary participation in the research was included in the questionnaire. A total of 103 questionnaires were found to be eligible for further analyses. A test of non-response biases was conducted by way of comparing the responses of early and late respondents. Independent t-tests statistics revealed the two-tailed values of $p>0.05$ for all constructs, indicating there were no significant statistical differences in the means of responses between early and late respondents.

\section{RESULT AND DISCUSSION}

Exploratory Factor Analysis (EFA) with principal components and varimax rotation was performed on the scale to the sample $(N=103)$. On each factor, the KMO was 0.834 which exceeded the threshold of 0.80 (Hair et al., 1988) and the Bartlett test was significant at $<0.05$ (Malhotra, 2009).

Results of EFA suggested two items of the scale were eliminated for psychometric considerations such as the failure of the items to load on any emergent factor, the factor had an inappropriate value of 
Cronbach alpha coefficient (less than 0.70) and/or insufficient number of loading items (less than three). The remaining 10 items yielded a two-factor solution with six items loaded on factor 1 (code embeddedness) and four items on factor 2 (code implementation). Altogether, the two factors explained $53.84 \%$ of total variance in the data. The summary EFA results are reported in Table 1.

As shown in the table, a number of two factors and their corresponding items were identified. The eigenvalue of each factor was greater than the recommended value of 1.00 (de Vaus, 2014; Hair, Black, Babin, \& Anderson, 2019). The factor loading coefficient of each item to its respective factor was above the acceptable limit of 0.50 (Hair et al. 2019).

\section{Reliability and Validity}

As depicted in Table 1, the Cronbach alpha coefficient for each construct was greater than 0.70 (Nunnally, 1994) suggesting that the two constructs were reliable. The content validity of the constructs was assured by employing the existing widely-used measurements combined with back translation procedures and a pre-test. Table 1 also shows that all individual constructs had eigenvalues exceeding 1.00 (Hair et al. 2019) indicating that the convergent validity of each construct was confirmed. To assess discriminant validity of the constructs their individual alpha were compared against the correlation coefficients between the two constructs.

As demonstrated in Table 2 the alpha coefficients were higher than the correlation coefficients across all constructs, indicating the discriminant validity of the measurement models was secured (Sharma \& Patterson, 1999).

The primary indicator of the staff's attitudes towards code of ethics was the mean score. The total mean scores for code embeddedness and code implementation were 3.10 and 3.47 out of the 5-point Likert scale, respectively (see Table 2) which mean they were slight above the midpoints of the scales. Therefore, Hypothesis $1 \mathrm{a}$ and $1 \mathrm{~b}$ were supported. Table 3 displays the mean scores from the entire sample for the ten items.

As shown in Table 3 the mean scores for items 1, 2 and 3 are below the midpoints of the scales. The remaining items have mean scores above the midpoints of the scales. Descriptive statistics for the ten items can be seen in Table 4.

Table 1. Summary of Exploratory Factor Analysis Results

\begin{tabular}{lccccc} 
Construct & $\begin{array}{c}\text { Number of } \\
\text { item }\end{array}$ & $\begin{array}{c}\text { Loadings } \\
\text { (range) }\end{array}$ & $\begin{array}{c}\text { Communalities } \\
\text { (range) }\end{array}$ & $\begin{array}{c}\text { Eigen } \\
\text { Value }\end{array}$ & $\begin{array}{c}\text { Alpha } \\
\text { Coefficient }\end{array}$ \\
Code Embeddedness & 6 & $0.629-0.780$ & $0.482-0.631$ & 4.407 & 0.831 \\
Code Implementation & 4 & $0.652-0.793$ & $0.434-0.655$ & 1.276 & 0.735 \\
\hline
\end{tabular}


Table 2. Descriptive statistics of used variables in this research

\begin{tabular}{lll}
\hline Construct & 1 & 2 \\
1. Code embeddedness & $\underline{\mathbf{0 . 8 3}}$ & \\
2. Code implementation & $0.549^{* *}$ & $\underline{\mathbf{0 . 7 3}}$ \\
Mean & 3.10 & 3.47 \\
Standard deviation & 0.33 & 0.64 \\
Number of items & 6 & 4 \\
\hline
\end{tabular}
Notes:
The bold, italic, underlined numbers in the diagonal indicate the alpha coefficients for individual constructs. The numbers under the diagonal denote the coefficient correlation between the individual constructs.
** Correlation is significant at the 0.01 level (2-tailed)

Table 3. Means and standard deviations for the entire sample

\begin{tabular}{|c|c|c|c|}
\hline No & Item & & \\
\hline & Code embeddedness & Mean & $\mathrm{SD}$ \\
\hline 1 & The ethics code serves as "window dressing" only in this organization & 2.38 & 1.06 \\
\hline 2 & $\begin{array}{l}\text { The average employee in this organization accepts the ethics code and } \\
\text { its requirements }\end{array}$ & 3.98 & 0.79 \\
\hline 3 & $\begin{array}{l}\text { The ethics code is effective in discouraging unethical behavior in this } \\
\text { organization }\end{array}$ & 2.37 & 0.90 \\
\hline 4 & $\begin{array}{l}\text { The ethics code serves only to maintain the organization's public } \\
\text { image }\end{array}$ & 2.65 & 1.01 \\
\hline 5 & $\begin{array}{l}\text { The average employee in this organization is guided by ethics code } \\
\text { every day }\end{array}$ & 3.68 & 0.61 \\
\hline 6 & $\begin{array}{l}\text { The average employee in this organization fully understand ethics } \\
\text { code and its requirements }\end{array}$ & 3.49 & 0.70 \\
\hline & Cod & & \\
\hline 1 & $\begin{array}{l}\text { Employees are required to acknowledge that they have read and } \\
\text { understood the ethics code }\end{array}$ & 3.50 & 0.83 \\
\hline 2 & $\begin{array}{l}\text { Employees learn about the ethics code through required orientation } \\
\text { and/or training }\end{array}$ & 3.52 & 0.96 \\
\hline 3 & $\begin{array}{l}\text { The organization has established procedures for employees to ask } \\
\text { questions about ethics code requirements. }\end{array}$ & 3.36 & 0.76 \\
\hline 4 & The code of ethics is widely distributed throughout the organization & 3.60 & 0.90 \\
\hline
\end{tabular}


Table 4. Individual mean scores of code embeddedness and code implementation by occupation (Independent t-test)

\begin{tabular}{|c|c|c|c|c|c|c|c|}
\hline \multirow[t]{2}{*}{ No } & \multirow[t]{2}{*}{ Item } & \multicolumn{2}{|c|}{ Academics } & \multicolumn{2}{|c|}{$\begin{array}{c}\text { Non- } \\
\text { academics }\end{array}$} & \multirow[t]{2}{*}{$\begin{array}{c}\mathrm{t} \\
\text { value }\end{array}$} & \multirow[t]{2}{*}{ Sig } \\
\hline & & Mean & SD & Mean & SD & & \\
\hline 1 & $\begin{array}{l}\text { The ethics code serves as "window dressing" } \\
\text { only in this organization }\end{array}$ & 2.49 & 0.97 & 2.27 & 1.16 & 1.06 & 0.08 \\
\hline 2 & $\begin{array}{l}\text { The average employee in this organization } \\
\text { accepts the ethics code and its requirements }\end{array}$ & 4.04 & 0.82 & 3.92 & 0.80 & 0.74 & 0.57 \\
\hline 3 & $\begin{array}{l}\text { The ethics code is effective in discouraging } \\
\text { unethical behavior in this organization }\end{array}$ & 2.39 & 0.86 & 2.35 & 0.86 & 0.60 & 0.57 \\
\hline 4 & $\begin{array}{l}\text { The ethics code serves only to maintain the } \\
\text { organization's public image }\end{array}$ & 2.58 & 0.91 & 2.71 & 0.95 & 0.62 & 0.31 \\
\hline 5 & $\begin{array}{l}\text { The average employee in this organization is } \\
\text { guided by ethics code every day }\end{array}$ & 3.71 & 0.58 & 3.65 & 0.65 & 0.43 & 0.36 \\
\hline 6 & $\begin{array}{l}\text { The average employee in this organization } \\
\text { fully understand ethics code and its } \\
\text { requirements }\end{array}$ & 3.41 & 0.67 & 3.56 & 0.70 & 1.06 & 0.89 \\
\hline & & & & & & & \\
\hline 1 & $\begin{array}{l}\text { Employees are required to acknowled } \\
\text { they have read and understood the ethic }\end{array}$ & 3.39 & 0.83 & 3.60 & 0.82 & 1.26 & 0.79 \\
\hline 2 & $\begin{array}{l}\text { Employees learn about the ethics code through } \\
\text { required orientation and/or training }\end{array}$ & 3.61 & 0.96 & 3.44 & 0.96 & 0.88 & 0.74 \\
\hline 3 & $\begin{array}{l}\text { The organization has established procedures } \\
\text { for employees to ask questions about ethics } \\
\text { code requirements. }\end{array}$ & 3.27 & 0.80 & 3.44 & 0.73 & 1.11 & 0.45 \\
\hline 4 & $\begin{array}{l}\text { The code of ethics is widely distributed } \\
\text { throughout the organization }\end{array}$ & 3.63 & 0.96 & 3.58 & 0.85 & 0.28 & 0.30 \\
\hline
\end{tabular}

As shown in Table 4, the means of the academic' and non-academic staff' scores on each of the items are different. To determine whether these differences are significant or not detailed independent $\mathrm{t}$ tests were conducted on the individual items of the scales. The results suggested no differences in the mean scores of the academic compared with those of the nonacademics in any one of the scale items (see Table 4). Thus, the remaining two hypotheses of this research that there would be no significant differences between academic and non-academic staff with regard to their attitudes toward the embeddedness (H2a) and the implementtation $(\mathrm{H} 2 \mathrm{~b})$ of their institutional code of ethics were supported

The purpose of this research was to examine the attitudes of academic and nonacademic staff of a denominational higher education institution in Indonesia toward their existing institutional code of ethics. It also investigated whether differences in the attitudes existed between the two groups. Results revealed no differences were found.

With regard to the degree of the attitudes findings of this research suggested both academic and non-academic staff arrived to an agreement that the code of ethics was moderately embedded and implemented within their institution. This was indicated by the total mean scores for code embeddedness and code implementtation which were slightly above the midpoints of the scales (3.10 and 3.47, respectively). Implicit in the findings was that both groups exhibited a positive attitude towards their institutional code of ethics in that they welcomed the presence of the code in their institution. 
Examination on the individual items supports this conjecture. As shown in Table 4 moderate scores of means were found in the responses to the statements of "the average employee in this organization accepts the ethics code and its requirements" ( $\mathrm{M}=3.98)$; 'the average employee in this organization is guided by ethics code every day" ( $M=3.68)$; and "the average employee in this organization fully understand ethics code and its requirements" $(M=3.49)$.

Respondents also believed that there were attempts of the institution to make the code of ethics well- implemented. This was evidenced by the means scores for two items that were somewhat above the midpoint of the scales, namely, "employees are required to acknowledge that they have read and understood the ethics code" $(\mathrm{M}=3.50)$; "the code of ethics is widely distributed throughout the organization" $(\mathrm{M}=3.60)$. In addition, respondents admitted that appropriate means have been created to support the implementation of the code. This was shown by moderate scores of means for responses to the following items: "employees learn about the ethics code through required orientation and/or training" $(\mathrm{M}=3.52)$; and "the organization has established procedures for employees to ask questions about ethics code requirements" $(\mathrm{M}=3.36)$.

Interestingly, respondents seemed to be rather sceptical towards the positive impact of the code. This was indicated by the mean scores for three items that were below the midpoint of the scales, namely, "the ethics code serves as "window dressing" only in this organization" ( $\mathrm{M}=$ 2.38); "the ethics code is effective in discouraging unethical behavior in this organization" $(\mathrm{M}=2.37)$ and "the ethics code serves only to maintain the organization's public image" $(\mathrm{M}=2.65)$.

A possible explanation for these negative attitudes perhaps relates to the less rigidity of code enforcement (Adams et al, 2001). Although a code would be effective when it is embedded and wellcommunicated in the culture of an organization (Stevens, 1999) consequences for violation (Singh, 2011) and particularly clear treatment to those who break the code (Ibrahim et al, 2010) are foremost. Furthermore, anonymity and confidentiality of those who report the violation (McDonald, 2009) should be guaranteed. Dobson (2003) emphasizes the importance of acculturation as it serves as implicit education into a certain moral value system that makes employees aware of acceptable behavior within an organization. The lack of uniform understanding of appropriate of the code content (Farrell, Cobbin, \& Farrell 2002) perhaps is another explanation. While in general the respondents stated that they fully understood the code it was likely that the understanding was diverse. This clearly indicates that effective communication and education of the code to employees is crucial for the institution.

The positive attitudes of staff toward their institutional code of ethics as revealed in the findings of this research corroborated the previous research on codes of ethics in higher education institutions conducted by Rezzae et al (2001). The facts that the respondents of this research perceived that the code only served as "window dressing" and maintained the institution's public image were indicative of their disbelief in the real impact of the code on the institution. This is in line with the notion of Brooks (1989) that problems with codes of ethics relate to compliance. Benson (1989) also reports many organizations have attempted to enforce their codes but there is limited evidence as to rigidity of enforcement. 


\section{CONCLUSION AND RECOMMEN- DATIONS}

\section{Conclusions}

In conclusion, this research built upon existing research focused on academic and non-academic staff of a higher education institution to determine their attitudes toward a code of ethics. Both groups were shown to be more alike than different. The lack of differences is probably suggestive to the other factors rather than merely occupational types.

\section{Managerial Implications}

From a managerial standpoint, the findings of this research provided institutional leaders with evidence that both academic and non-academic staff were more alike than different in their attitudes toward their code of ethics. In other words, occupation might not be a good single predictor in this research. The lack of occupational influence on the attitudes implied that the code was not discriminatory against any one of the groups. However, as early mentioned, both groups showed their scepticism towards the effectiveness of the code especially in regards to discouraging unethical behaviors. The following are possible actions the institutional leaders need to take

While a code of ethics is instrumental in preventing unethical behavior the mere existence of the code in an organization does not signify that the organization adopts moral principles in practices (Ely, Henderson, \& Wachsman, 2013; Wotruba et al, 2001). The effectiveness of a code of ethics requires communication, monitor and enforcement of the code. Above all, the code should be translated into institutional practice that shows no preferential treatment to any employee regardless of their position within the organization. While the first three requirements might have been exercised the latter might not be the case in the institution investigated in this research. Clearly, leaders of the institution need to create a culture that makes all requirements possible. Such a culture requires the institution to explicitly provide current, new and future employees with behaviors that are permissible and not permissible. Similarly the consequences for violating codes should also be clearly stated. Indeed, the degree of discipline should be in accordance with the nature of violation. When these things are internalized in the values of individuals and manifested in individual behavior they become acculturated by the day-to-day acceptable behaviors (Dobson, 2003) which in turn facilitate the effectiveness of a code of ethics. In this regards, the roles of institutional leaders are very essential. They should be able to serve as role models of ethical behaviors (Koh \& Boo, 2004) and inculcate in employees the importance of ethics in workplace (Doig \& Wilson, 1998). Aligning the code with compensation plan might help too (Coughlan, 2005).

\section{Scholarly Implications}

From a scholarly perspective, this research was conducted within an Indonesian setting and thus served to validate a model of code embeddedness and code implementation McCabe et al (1996) designed primarily for use within a western cultural context. The empirical evidence of this research shows this model is relatively robust within the context under investigation.

Although this research did not find any statistically significant differences in the attitudes between academic and nonacademic staff of a denominational higher education institution it was still considered important due the limited number of research, if any, on codes of ethics within the higher education institutions in Indonesia. Thus, this research also aimed to fill the gap in the existing body of literature on this area. 


\section{Limitations}

The main limitation of this research concerns data from a single institution. This institution indeed is not representative of all denominational higher education institutions in Indonesia hence caveats must be offered regarding the generalizability of the results. Considering attitudes toward a code of ethics is a sensitive topic the tendency of respondents to express opinion that socially undesirable might occur.

\section{Future Directions}

Replication of this research should be conducted with bigger sample sizes including other denominational and nondenominational institutions to help minimize the difficulty of this research in dealing with only a single institution. Since there are no statistically significant differences in the attitudes between academic and non-academic staff future investigations should be conducted to look for other possible causes of the differences such as gender, education, length of service and positions of the respondents within the institution.

\section{REFERENCES}

Adams, J., Tashchian, A., \& Shore, T. (2001). Codes of ethics as signals for ethical behavior. Journal of Business Ethics, 29, 199-211.

Adelstein, J., \& Clegg, S. (2016). Code of ethics: A stratified vehicle for compliance. Journal of Business Ethics, 138(1), 53-66.

Angelidis, J., \& Tomic, I. (2009). Managers' attitudes toward codes of ethics: Are there gender differences? Journal of Business Ethics, 90, 343353.

Arnold, D. G., Beauchamp, T.L., \& Bowie, N.L. (2013). Ethical theory and business. Boston: Pearson Education.
Ashkanasy, N., Falkus, S., \& Callan, V. (2000). Predictors of ethical code use and ethical tolerance in the public sector. Journal of Business Ethics, 25, 237-253.

Benson, G.C.S. (1989). Codes of ethics, Journal of Business Ethics 8(5), 305319.

Braxton, J. M., \& Bray, N.J. (2012). Introduction: the importance of codes of conduct for academia. New Directions for Higher Education, 160, 1-4.

Bray, N. J., Molina, D. K., \& Swecker, B.A. (2012). Organizational constraints and possibilities regarding codes of conduct. New Directions for Higher Education, 160, 73-87.

Brooks, L. J. (1989) Ethical codes of conduct: deficient in guidance for the Canadian Accounting Profession. Journal of Business Ethics. 8, 325255.

Chu, C., Gotti, G., Kang, T., \& Wolfe, M.C. (2018). Corporate codes of ethics, national culture, and earnings discretion: international evidence. Journal of Business Ethics: 151(1), 141-163.

Couch, S., \& Dodd, S. (2005). Doing the right thing: Ethical issues in higher education. Journal of Family and Consumer Sciences, 97(3), 20-26.

Coughlan, R. (2005). Codes, values and justifications in the ethical decisionmaking process, Journal of Business Ethics 59(1-2), 45-53.

de Vaus, D. (2014). Surveys in social research (6th ed). Routledge/Taylor and Francis Group.

Dobson, J. (2003). Why ethics codes don't work, Financial Analysts Journal, 59(6), 29-34.

Doig, A., \& Wilson, J. (1998). The effectiveness of codes of conduct, Business Ethics: A European Review 7(3), 140-149. 
Ely, J. J., Henderson, L., \& Wachsman, Y. (2013). Testing the effectiveness of the university honor code. Academy of Educational Leadership Journal, 18(3), 1-10.

Farrell, B. J., Cobbin, D. M., \& Farrell, H. M. (2002). Codes of ethics: Their evolution, development and other controversies. Journal of Management Development 21(2), 152-163.

Ford, R .C., \& Richardson, W.D. (1994). Ethical decision making: A review of the empirical literature. Journal of Business Ethics, 13(3), 205-221

Forster, D. J. (2012). Codes of ethics in Australian education: Towards a national perspective. Australian Journal of Teacher Education, 37(9), 1-17.

Fiedler, C. R., \& van Haren, B. (2009). A comparison of special education administrators' and teachers' knowledge and application of ethics and professional standards. The Journal of Special Education, 43(3), 160173.

Hair, J., Black, W., Babin, B., \& Anderson, R. (2019). Multivariate data analysis. Cengage, U.K.

Hatier, C. (2014). The morality of university decision-makers, Studies in Higher Education, 39(6), 10851096.

Ho, C., \& Oladinrin, O. (2016). Evaluation of ethical codes implementation - a fuzzy approach. Facilities. 34(13), 924-955.

Ibrahim, N., Angelidis, J. \& Tomic, I.M. (2009). Managers' attitudes toward codesof ethics: Are there gender differences?.Journal of Business Ethics (90): 343 - 353.

Kaptein, M., \& Schwartz, M.S. (2008). The effectiveness of business codes: a critical examination of existing studies and the development of an integrated research model. Journal of Business Ethics, 77, 111-127.
Kaptein, M. (2011). Toward effective codes: Testing the relationship with unethical behavior. Journal of Business Ethics. 99(2), 233-251.

Ki, E.J., Lee, J., \& Choi, H.L. (2012). Ki, E., Lee, J., and Choi, H. (2012). Factors affecting ethical practice of public relations professionals within public relations firms. Asian Journal of Business Ethics, 1, 123-141.

Lam, K., \& Shi, G. (2008). Factors Affecting Ethical Attitudes in Mainland China and Hong Kong. Journal of Business Ethics, 77(4), 463-479.

Lopez, Y., Rechner, P., \& OlsonBuchanan, J. (2005). Shaping ethical perceptions: An empirical assessment of the influence of business education, culture, and demographic factors. Journal of Business Ethics. 60, 341-358

Lukviarman, N., Ma'ruf, S., \& Hamidi, M.L. (2018). Religious feeling, morality and ethical feelings: The case study on Indonesia. Problems and Perspectives in Management, 16, 444-452.

Magalhães, Á.B., Pereira, M.N.S., Nascimento, B.N.P., \& de Lima, M.D.S. (2016). Revista Bioética 24(2), 322-331.

Malhotra, N.K. (2009). Marketing research: An applied orientation, Englewood Cliffs: Prentice Hall.

Mayo, D. (2010). Comparisons of perceptions of North Carolina community college chief academic officers and faculty on codes of conduct. Doctoral Dissertation. East Carolina University.

McCabe, D.L., Trevino, L.K., \& Butterfield, K.D (1996). The influence of collegiate and corporate codes of conduct on ethics-related behaviour in the workplace, Business Ethics Quarterly 6(4), 461-476

McDonald, G.M. (2009). An anthology of codes of ethics, European Business Review 21(4), 344-372. 
McKay, R.B., Kidwell, L.A., \& Kling, J.A. (2007). Faculty ethics from the perspective of College of Business Administration, Journal of Legal, Ethical and Regulatory Issues, 10(1), 105-24.

Melgoza, P. \& Smith, J. (2008). Revitalizing an existing honor code program. Innovative Higher Education 32, 209-219.

Mujtaba, B.G., Tajaddini, R., \& Chen, L. (2011). Business ethics perceptions of public and private sector Iranians. Journal of Business Ethics. 104, 433447.

Nunnally, J.C. (1994). Psychometric theory, $\left(5^{\text {th }}\right.$ ed. $)$, New York: McGraw-Hill Book Company.

Pauli, K.P., Arthur, T.J. \& Price, R.A. (2014). Upon this Rock: The effect of an honor code, religious affiliation, and ethics education on the perceived acceptability of cheating. Journal of Leadership, Accountability and Ethics 11(1), 97110.

Poon, J.M.L. \& Raja A.A., (2011) Selected ethical issues in the analysis and reporting of research: survey of Business School Faculty in Malaysia. Journal of Academic Ethics, 9 (4), 307-322.

Rezaee, Z., Elmore, R.C., \& Szendi, J.Z. (2001). Ethical behavior in higher educational institutions: The role of the code of conduct, Journal of Business Ethics 30 (2), 171-183.

Rothman, P. (2017). Ethics in Higher Education: A study of the perceived ethical climate of administrators and faculty at a higher education institution; Education Doctoral. Paper 287.

Ruiz-Palomino, P., Martinez-Canas, R., Rodrigo, J. \& Díaz-García, M. (2015). Level of coherence among ethics program components and its impact on ethical intent. Journal of Business Ethics, 128(4), 725-742.
Sánchez, I., Rodríguez-Domínguez, L., \& Frias-Aceituno, J.V. (2015). Board of directors and ethics codes in different corporate governance systems. Journal of Business Ethics, 131(3), 681-698.

Schwartz, M.S. (2004). Effective corporate codes of ethics: perceptions of code users. Journal of Business Ethics, 55, 321-341.

Sharma, N. \& Patterson, P.G. (1999). The impact of communication effectiveness and service quality on relationship commitment in consumer, professional services, Journal of Services Marketing, 13(2), 151 170

Singh, J.B. (2011) Determinants of the effectiveness of corporate codes of ethics: An empirical study. Journal of Business Ethics, 101, 385 - 395.

Stevens, B. (1999). Communicating ethical values: A study of employee perceptions. Journal of Business Ethics. 20(2), 113-120.

Stohl, C., Stohl, M., \& Popova, L.A (2009). New Generation of Corporate Codes of Ethics. Journal of Business Ethics, 90(4), 607-622

Tabsh, S., El Kadi, H., \& Abdelfatah, A. (2012). Faculty response to ethical issues at an American university in the Middle-East. Quality Assurance in Education, 20(4), 319-340.

Valentine, S., \& Barnett, T. (2002). Ethics Codes and Sales Professionals' Perceptions of Their Organizations' Ethical Values. Journal of Business Ethics. 40 (3), 191-200.

Valentine, S., Hanson, S., \& Fleischman, G. (2019).The presence of ethics codes and employees' internal locus of control, social aversion/ malevolence, and ethical judgment of incivility: A study of smaller organizations. Journal of Business Ethics. 160, 657-674.

Velasquez, M.G. (2011). Business ethics: Concepts and cases. Englewood Cliffs, N.J: Prentice-Hall. 
Weber, J. (2006). Implementing an organizational ethics program in an academic environment: The challenges and opportunities for the Duquesne university schools of business. Journal of Business Ethics. 65, 23-42.

Weegar, M. A. (2007). Promoting Ethical Practices within Institutions of Higher Education. Proceedings of the 2007 Association for Business Communication Annual Convention. 2007 The Association for Business Communication October 10-12, 2007 Washington, D.C.

Wotruba, T., Chonko, L., \& Loe, T. (2001). The impact of ethics code familiarity on manager behavior. Journal of Business Ethics. 33(1), 59-69.

Yahr, M. A, Bryan, L. D., \& Schimmel, K. (2009). Perceptions of college and university codes of ethics. Journal of Academic and Business Ethics, 9, 1 10. 